University of Nebraska - Lincoln

DigitalCommons@University of Nebraska - Lincoln

Faculty Publications: Agricultural Leadership, Education \& Communication Department
Agricultural Leadership, Education \& Communication Department

$1-13-2007$

\title{
Effects of Gender, Education, and Age upon Leaders' Use of Influence Tactics and Full Range Leadership Behaviors
}

John E. Barbuto Jr.

University of Nebraska - Lincoln, jbarbuto@unlnotes.unl.edu

Susan Fritz

University of Nebraska - Lincoln, sfritz1@unl.edu

Gina S. Matkin

University of Nebraska - Lincoln, gmatkin1@unl.edu

David B. Marx

University of Nebraska - Lincoln, david.marx@unl.edu

Follow this and additional works at: https://digitalcommons.unl.edu/aglecfacpub

Part of the Other Public Affairs, Public Policy and Public Administration Commons

Barbuto, John E. Jr.; Fritz, Susan; Matkin, Gina S.; and Marx, David B., "Effects of Gender, Education, and Age upon Leaders' Use of Influence Tactics and Full Range Leadership Behaviors" (2007). Faculty Publications: Agricultural Leadership, Education \& Communication Department. 40.

https://digitalcommons.unl.edu/aglecfacpub/40

This Article is brought to you for free and open access by the Agricultural Leadership, Education \& Communication Department at DigitalCommons@University of Nebraska - Lincoln. It has been accepted for inclusion in Faculty Publications: Agricultural Leadership, Education \& Communication Department by an authorized administrator of DigitalCommons@University of Nebraska - Lincoln. 


\title{
Effects of Gender, Education, and Age upon Leaders' Use of Influence Tactics and Full Range Leadership Behaviors
}

\author{
John E. Barbuto Jr, Susan M. Fritz, Gina S. Matkin*, \& David B. Marx \\ University of Nebraska-Lincoln
}

*Corresponding author - G. S. Matkin, Department of Agricultural Leadership Education and Communication, University of Nebraska-Lincoln, 300 Ag Hall, P.O. Box 830709, Lincoln, NE 68588-0709, USA . Email: gmatkin@unlnotes.unl.edu

\begin{abstract}
Relationships of gender, age, and education to leadership styles and leaders' influence tactics were examined with 56 leaders and 234 followers from a variety of organizations. Leadership behaviors were measured with the Multi-factor Leadership Questionnaire (MLQ - rater version). Influence tactics were measured with Yukl's Influence Behavior Questionnaire (IBQ). Multivariate Analysis of Variance (MANOVA) was used to test behavioral differences attributed to leaders' gender, age, and education groups, as well as the interaction of age and education with gender. Results show that gender produced a small direct effect on leadership behaviors. The interaction of gender and education produced consistent differences in leadership behaviors. Implications for future research are provided, and a call for reanalysis of previously published work is advised.
\end{abstract}

Keywords - Gender, Influence tactics, Leadership

For every study that has shown differences in leadership behaviors based on gender (e.g., Carless, 1998; Druskat, 1994; Helgeson, 1990; Rosener, 1990; Thacker, 1995), another has shown no differences at all (e.g., Bartol \& Martin, 1986; Bass \& Stogdill, 1990; Nieva \& Gutek, 1981; van Engen, van der Leeden, \& Willemsen, 2001). Some researchers (e.g., Eagly, Johannesen-Schmidt, \& van Engen, 2003; Leithwood \& Jantzi, 1997; Lewis, 1998; Thacker, 1995) have called for inclusion of contextual variables and use of more complex research designs to test the effect of gender on leadership behavior. We have answered this call by testing the interaction effects of age and educational level of leaders as a possible explanation for some of the mixed findings over the past 30 years in gender and leadership research.
Demographic variables such as gender, age, and educational level have been used to predict many behaviors, including effectiveness (Eagly, Karau, \& Makhijani, 1995; Thompson, 2000), communication style (Kirtley \& Weaver, 1999), decision making (Ganzel, 1999; Radecki \& Jaccard, 1996), productivity (Kovar \& Overdorf, 1995; Wilson \& Hossain, 1999), participation (Itzhaky \& York, 2000; O’Connor, 1996; Williamson, 2000), conflict style (Chusmir \&Mills, 1989; Duane, 1989; P. S. Sorenson, Hawkins, \& R. L. Sorenson, 1995), success (Blank \& Levesque, 1993; Chusmir \& Parker, 1992; Sutherland, 1999), and power (Jenkins, 2000; Lips, 2000). Although a great deal of research has concerned the relationship between leadership and gender, few researchers have explored the relationship between leadership and age, and fewer still the relationship between leadership and educational level. In the present study, we examined all three variables as predictors of Full Range Leadership and influence tactics.

The Full Range Leadership model, operationalized by Bass (1985), encompasses laissez-faire (lack of leadership), transactional, and transformational leadership behaviors. Transactional leadership is characterized as management by exception (corrective actions) and contingent rewards (tangible exchanges). Transformational leadership is characterized as idealized influence (symbol of the vision), individualized consideration (strong one-on-one relationship, developmental growth), intellectual stimulation (encouragement of new thinking patterns), and inspirational motivation (creation of a new sense of vision and purpose). Across a number of studies of the Full Range Leadership model as a predictor of a variety of outcomes in organizations (e.g., employee satisfaction, effort, or motivation; organizational effectiveness; performance), 
strong relationships have been found between transformational leadership and most positive outcomes (Bass \& Stogdill, 1990). However, much less is known about the antecedents of leadership behavior. Likewise, a great deal of research has concerned the relationship between the Full Range Leadership model and influence tacticsthe actual behaviors used by an agent to change the attitudes, opinions, or behaviors of a target (Hughes, Ginnett, \& Curphy, 1993). Previous researchers (Kipnis, Schmidt, \& Wilkinson, 1980; Yukl \& Falbe, 1990) have categorized influence tactics in a number of ways. Yukl and others (Falbe \& Yukl, 1992; Yukl \& Falbe, 1990; Yukl, Falbe, \& Youn, 1993; Yukl \& Tracey, 1992) identified nine influence tactics: legitimizing, rational persuasion, inspirational appeal, consultation, exchange, personal appeals, ingratiation, pressure, and coalition. Barbuto, Scholl, Hickox and Boulmetis (2001) classified Yukl's nine influence tactics as either "hard" or "soft" based on targets' levels of resistance in relation to leader behavior. Hard, or forceful tactics, include legitimizing, exchange, pressure, and coalition. Soft tactics are more interpersonal and include rational persuasion, inspirational appeals, consultation, ingratiation, and personal appeals (Barry \& Shapiro, 1992). Although researchers have explored the emergence of these tactics from the Full Range Leadership model, much less is known about the antecedents of these behaviors.

\section{Gender}

Gender and leadership - The most researched of the three independent variables in the present study is gender; there has been a strong focus on stereotyping and its effect on women's behaviors (e.g., I. K. Broverman, Vogel, D. M. Broverman, Clarkson, \& Rosenkrantz, 1972; Cann\& Siegfried, 1990; Davis, Best, \& Williams, 1982; Deaux \& Lewis, 1984; Schein, 1973; Schein, Mueller, \& Jacobson, 1989; Zanna \& Pack, 1975) and on perceptions of women leaders (e.g., Jacobson \& Effertz, 1974; Porter, Geis, \& Jennings, 1983).

Eagly and Johnson (1990) conducted a meta-analysis of gender and leadership based on 162 reports that included data on the leadership styles of women and men. They found significant gender differences in the reported use of democratic or participatory styles of leadership in three types of organizational settings: experimental (i.e., laboratory studies), assessment (i.e., settings in which researchers assessed the leadership styles of people not selected for leadership roles), and formal (i.e., settings in which researchers assessed the leadership styles of people in formal leadership roles). Men were more likely than women to use autocratic, or direct, controlling styles. Although women were found to have a more interpersonal style in experimental and assessment studies, they did not differ from men in formal organizational settings (Eagly \& Johnson, 1990). This finding contrasts with gender-stereotypic expectations that women embrace more interpersonal leadership styles, whereas men are more task-oriented.

A subsequent meta-analysis of 58 studies of the emergence of leaders in groups initially without leaders showed that men emerged as leaders more often than women did (Eagly \& Karau, 1991). However, women emerged slightly more often than men in the role of a "social leader" or facilitator, who contributes to morale and good interpersonal relations. Men's leadership tended to emerge in the more task-oriented aspects of interaction. The researchers found that women and men became more equal in their leadership contributions overall in groups that had existed for longer periods of time.

One clear problem in the study of gender and leadership is that leadership has traditionally been studied using masculine norms as the standards for behaviors (Chliwniak, 1997). Thus, men often are viewed as better leaders, and women often adopt masculine behaviors to fit into male-dominated hierarchical structures and systems (Acker, 1989; Gutek, 1985). An additional complication is that women are expected simultaneously to behave like leaders (authoritative, confident) and to be feminine (friendly, kind, considerate toward others). The more women violate the standards for their gender, the more they may be penalized by prejudiced reactions that would not be directed toward their male counterparts (Eagly, Makhijani, \& Klonsky, 1992).

Researchers have examined gender and transformational leadership from a variety of perspectives. Carless (1998) and Druskat (1994) suggested that transformational leadership may be a more feminine style of leading, but Komives (1991) found no significant differences between female and male managers' self-ratings of transformational leadership traits, except for intellectual stimulation, an area in which men rated themselves significantly higher than women did. Men attributed their use of power and direct styles to transformational leadership, whereas women attributed their use of relational styles to transformational leadership (Komives, 1991).

Hackman, Furniss, Hills and Paterson (1992)found a significant, positive correlation between perceived gender characteristics and some transformational leader behaviors. Leaders who displayed both high masculine and high feminine characteristics scored higher on transformational leadership factors, which indicates that transformational leader behaviors require a gender balance. Another study of perceptions of transformational leadership behavior (Carless, 1998) showed that superiors rated fe- 
male managers as more transformational than male managers. Female managers agreed; they rated themselves as more transformational than male managers rated themselves. Subordinates, however, evaluated the transformational behaviors of male and female managers equally.

In other studies women have been evaluated by subordinates as more transformational in both an organizational context (Bass \& Avolio, 1992) and a nontraditional (formal religious) setting (Druskat, 1994). Ojode, Walumbwa and Kuchinke (1999) found that both male and female students rated their instructors high in transformational behaviors, but male students were more likely than female students to view instructors as utilizing transactional leadership behaviors. Finally, a meta-analysis conducted by Eagly et al. (2003) showed women to be more transformational than men; the authors concluded that women may favor a transformational leader style because it provides them "with a means of overcoming the dilemma of role incongruity - namely, that conforming to their gender role can impede their ability to meet the requirements of their leader role" (p. 573).

Gender and influence tactics - Gender has been studied in its relationship to the perceived use of influence tactics, but such studies have produced mixed findings. Although most researchers have noted that men and women use different influence tactics (Carli, 1999; Carothers \& Allen, 1999; DuBrin, 1991; Lamude, 1993; White, 1988), many also reported that differences in circumstances correspond to the expectations of normative influence behaviors for men and women (Carli, 1999; Carothers \& Allen, 1999; Lamude, 1993). For example, Eagly et al. (1992) found women to be less effective than men when leading directly. Another study (Burgoon, Dillard, \& Doran, 1983) showed that participants were more persuaded by men who used a direct and aggressive influence strategy than by women who used the same strategy. Tepper, Brown and Hunt (1993) found that men who employed stronger upward influence tactics received higher performance ratings and more career-related mentoring than women who employed these same tactics.

\section{Age and Educational Level}

Very few studies have been done on age or educational level as they relate to leadership or influence tactics, and most studies on age and leadership are limited to either retirement (Chetkow-Yanoov, 1986; Cusack, 1994; Cusack \& Thompson, 1992) or adolescence (Bronfenbrenner, 1961; Schneider, Paul, White, \& Holcombe, 1999; Zacharatos, Barling \& Kelloway, 2000). Avolio (1994) examined the development of transformational leadership by linking leadership ratings to life events and experiences (e.g., self-ratings of life satisfaction, parental interest, moral standards of parents, high school extracurricular activities, school experience, and positive work experiences). Results indicated that some early life experiences were associated with self and follower ratings of transformational leadership; however, the associations were much weaker than anticipated. The author cited research design-related reasons for the results and suggested further refinements and continued study to link life events to the development of effective leadership behaviors - particularly transformational leadership.

\section{Gender, Age, and Education}

Studies of gender, age, and educational level as predictors of leadership style or leaders' use of influence tactics are nearly absent from the research literature. Ojode et al. (1999) examined the gender, age, and educational level of followers as predictors of perceptions of leader styles. Vecchio and Boatwright (2002) examined the gender and maturity (a combination of age and educational level) of followers as predictors of idealized styles of leadership. They found that employees with higher levels of education and greater job tenure expressed less preference for leader structuring (task-oriented behaviors); they also found that women (relative to men) expressed greater preference for leader considerateness (relationship-oriented behaviors).

A few studies included gender, age, and education as demographic variables in their examination of leadership styles. These studies produced mixed findings on the significance of the effects of these variables on leadership style. Three studies (Kazan, 2000; Payden, 1997; Thomas, 1996)showed differences in self-perceptions of leadership based on age, and one study (Rasor, 1995) showed that younger age in leaders predicted higher evaluations by both superiors and subordinates. Gender, age, and education all were found to predict a significant magnitude of team effectiveness (Taylor, 1998), as well as differences in servant leadership (a leadership philosophy where people choose to serve first, and then lead as a way of expanding service to individuals and institutions) or spirit in organizations (Horsman, 2001).

The most recent meta-analysis of gender and leadership (conducted by van Engen \& Willemsen, 2004) revealed mixed empirical evidence for gender differences in leadership style. The authors suggested that dichotomous conceptions of leadership styles (e.g., democratic versus autocratic), coupled with dichotomous variables such as gender or sex, may produce questionable results. They called for linking various dichotomies together "as if they 
Table 1 Multivariate analysis of variance summary for MLQ.

\begin{tabular}{|c|c|c|c|c|c|c|c|c|c|c|}
\hline \multicolumn{7}{|l|}{ MANOVA } & \multicolumn{4}{|l|}{ Univariate analysis of variance } \\
\hline Ind. variable & Wilks' & $F$ & $p$ & Roy's & $F$ & $p$ & Dep. variables & $F$ & $d f$ & $p$ \\
\hline \multirow[t]{13}{*}{ Education } & 0.86 & 1.49 & 0.068 & 0.12 & 1.81 & 0.050 & & & & \\
\hline & & & & & & & Transactional & 0.28 & 2 & 0.756 \\
\hline & & & & & & & Management by exœetion & 0.43 & 2 & 0.652 \\
\hline & & & & & & & Laisse-faire & 0.71 & 2 & 0.491 \\
\hline & & & & & & & Contingent reward & 0.77 & 2 & 0.466 \\
\hline & & & & & & & Transformational & 1.52 & 2 & .220 \\
\hline & & & & & & & Inspirational appeal & 0.33 & 2 & 0.717 \\
\hline & & & & & & & Idealized influence & 1.30 & 2 & 0.276 \\
\hline & & & & & & & Intellectual stimulation & 0.20 & 2 & 0.821 \\
\hline & & & & & & & Individualized consideration & $4.58^{*}$ & 2 & 0.011 \\
\hline & & & & & & & Extra effort & 0.26 & 2 & 0.821 \\
\hline & & & & & & & Effectiveness & 0.77 & 2 & 0.464 \\
\hline & & & & & & & Satisfaction & 1.04 & 2 & 0.356 \\
\hline \multirow[t]{13}{*}{ Age } & 0.83 & 1.46 & 0.079 & 0.14 & 2.14 & 0.017 & & & & \\
\hline & & & & & & & Transactional & 1.43 & 2 & 0.241 \\
\hline & & & & & & & Management by exœeption & 3.03 & 2 & 0.051 \\
\hline & & & & & & & Laissez-faire & 0.87 & 2 & 0.422 \\
\hline & & & & & & & Contingent reward & 1.38 & 2 & 0.254 \\
\hline & & & & & & & Transformational & $4.24^{*}$ & 2 & 0.016 \\
\hline & & & & & & & Inspirational appeal & 1.32 & 2 & 0.271 \\
\hline & & & & & & & Idealized influence & $4.19^{*}$ & 2 & 0.017 \\
\hline & & & & & & & Intelloctual stimulation & 3.00 & 2 & 0.052 \\
\hline & & & & & & & Individualized consideration & $5.48^{* *}$ & 2 & 0.005 \\
\hline & & & & & & & Extra effort & 1.90 & 2 & 0.153 \\
\hline & & & & & & & Effectiveness & $4.84^{* *}$ & 2 & 0.009 \\
\hline & & & & & & & Satisfaction & 1.66 & 2 & 0.193 \\
\hline \multirow[t]{13}{*}{ Educ $\times$ age } & 0.68 & 1.52 & 0.015 & 0.21 & 3.17 & 0.000 & & & & \\
\hline & & & & & & & Transactional & 1.49 & 4 & 0.206 \\
\hline & & & & & & & Management by exception & $2.51^{*}$ & 4 & 0.043 \\
\hline & & & & & & & Laissez-faire & 2.39 & 4 & 0.052 \\
\hline & & & & & & & Contingent reward & 1.46 & 4 & 0.215 \\
\hline & & & & & & & Transformational & $2.69^{*}$ & 4 & 0.033 \\
\hline & & & & & & & Inspirational appeal & $3.13^{*}$ & 4 & 0.016 \\
\hline & & & & & & & Idealized influence & $2.45^{*}$ & 4 & 0.048 \\
\hline & & & & & & & Intelloctual stimulation & 1.53 & 4 & 0.195 \\
\hline & & & & & & & Individualized consideration & 2.24 & 4 & 0.066 \\
\hline & & & & & & & Extra effort & 1.72 & 4 & 0.147 \\
\hline & & & & & & & Effectiveness & $3.9^{* *}$ & 4 & 0.005 \\
\hline & & & & & & & Satisfaction & 1.70 & 4 & 0.151 \\
\hline \multirow[t]{13}{*}{ Gender } & 0.94 & 0.98 & 0.473 & 0.07 & 0.98 & 0.473 & & & & \\
\hline & & & & & & & Transactional & 0.30 & 1 & 0.584 \\
\hline & & & & & & & Management by exception & 2.51 & 1 & 0.115 \\
\hline & & & & & & & Laissez-faire & 1.28 & 1 & 0.260 \\
\hline & & & & & & & Contingent reward & 3.43 & 1 & 0.065 \\
\hline & & & & & & & Transformational & 4.64 & 1 & 0.032 \\
\hline & & & & & & & Inspirational appeal & 2.03 & 1 & 0.156 \\
\hline & & & & & & & Idealized influence & 3.86 & 1 & 0.051 \\
\hline & & & & & & & Intelloctual stimulation & 3.64 & 1 & 0.058 \\
\hline & & & & & & & Individualized consideration & 3.28 & 1 & 0.072 \\
\hline & & & & & & & Extra effort & 3.82 & 1 & 0.052 \\
\hline & & & & & & & Effectiveness & 4.50 & 1 & 0.035 \\
\hline & & & & & & & Satisfaction & 9.18 & 1 & 0.003 \\
\hline \multirow[t]{3}{*}{ Educ $\times$ gender } & 0.84 & 1.32 & 0.148 & 0.14 & 2.06 & 0.022 & & & & \\
\hline & & & & & & & Transactional & 1.63 & 2 & 0.199 \\
\hline & & & & & & & Management by exception & $4.47^{*}$ & 2 & 0.013 \\
\hline
\end{tabular}


Table 1 (continued)

\begin{tabular}{|c|c|c|c|c|c|c|c|c|c|c|}
\hline \multicolumn{7}{|l|}{ MANOVA } & \multicolumn{4}{|l|}{ Univariate analysis of variance } \\
\hline Ind. variable & Wilks' & $F$ & $p$ & Roy's & $F$ & $p$ & Dep. variables & $F$ & $d f$ & $p$ \\
\hline & & & & & & & Laisse-faire & 1.96 & 2 & $\overline{0.143}$ \\
\hline & & & & & & & Contingent reward & 2.05 & 2 & 0.132 \\
\hline & & & & & & & Transformational & $5.32 * *$ & 2 & 0.006 \\
\hline & & & & & & & Inspirational appeal & $3.04 *$ & 2 & 0.050 \\
\hline & & & & & & & Idealized influence & $3.86^{*}$ & 2 & 0.023 \\
\hline & & & & & & & Intellectual stimulation & $3.04 *$ & 2 & 0.050 \\
\hline & & & & & & & Individualized consideration & $6.11 * *$ & 2 & 0.003 \\
\hline & & & & & & & Extra effort & $3.52 *$ & 2 & 0.032 \\
\hline & & & & & & & Effectiveness & $6.5^{* *}$ & 2 & 0.002 \\
\hline & & & & & & & Satisfaction & 3.02 & 2 & 0.051 \\
\hline \multirow[t]{13}{*}{ Age $\times$ gender } & 0.86 & 1.14 & 0.302 & 0.09 & 1.38 & 0.180 & & & & \\
\hline & & & & & & & Transactional & 2.29 & 2 & 0.104 \\
\hline & & & & & & & Management by exception & 2.13 & 2 & 0.121 \\
\hline & & & & & & & Laissez-faire & 1.22 & 2 & 0.298 \\
\hline & & & & & & & Contingent reward & 1.16 & 2 & 0.316 \\
\hline & & & & & & & Transformational & 0.51 & 2 & 0.603 \\
\hline & & & & & & & Inspirational appeal & 0.48 & 2 & 0.621 \\
\hline & & & & & & & Idealized influence & 0.28 & 2 & 0.757 \\
\hline & & & & & & & Intellectual stimulation & 0.36 & 2 & 0.701 \\
\hline & & & & & & & Individualized consideration & 1.25 & 2 & 0.287 \\
\hline & & & & & & & Extra effort & 0.21 & 2 & 0.809 \\
\hline & & & & & & & Effectiveness & 0.47 & 2 & 0.625 \\
\hline & & & & & & & Satisfaction & 0.46 & 2 & 0.635 \\
\hline
\end{tabular}

$* p<0.05$

$* * p<0.01$

represent aspects of the same underlying dimension" (p. 16) and noted that empirical evidence suggests a complex reality that ought to be reflected in research designs.

In the current study, we addressed this complexity by studying gender, age, and education individually, in addition to the interaction of education and age with gender, to explain differences in leader style and use of influence tactics. We expected that the distinct variables (gender, age, and educational level) would not significantly predict leaders' leadership behaviors or use of influence tactics. Consistent with the finding of Eagly et al. (2003) that older and more experienced women are more transformational, we expected the interaction of age and gender, as well as the interaction of educational level and gender, to explain differences in leader behavior. Specifically, we expected to find that women at higher age and educational levels would be more transformational and would use more soft influence tactics than would men at the same age and educational levels.

\section{Method}

Sample

Data were collected from 56 leaders and 234 raters employed in a variety of industries, governmental agencies, and educational institutions in both rural and urban settings. The average age was 43 years $(\mathrm{SD}=8.9)$. Sixty-four percent of the leaders and $62 \%$ of the raters were women. Leaders had an average job tenure of 9.9 years; educational levels among leaders ranged from high school diploma $(15 \%)$, to bachelor's degree (64\%), to master's degree (21\%). Raters had an average job tenure of 9.8 years; their educational levels ranged from high school diploma (29\%), to bachelor's degree (34\%), to master's degree (37\%).

\section{Measures}

Four subscales of leaders' transformational behaviors (inspirational motivation, idealized influence, individualized consideration, and intellectual stimulation) were measured with the Multi-factor Leadership Questionnaire (MLQ; Bass, 1985). The four subscales each consist of four behavioral items that are rated on a 5-point Likert-type scale that ranges from 0 (never) to 4 (almost always). The measure has generally performed well in past studies according to all validation criteria and has undergone extensive testing to confirm its reliability and validity (Antonakis, 2001). Psychometric properties in the present study were similar to those reported by previous researchers; the four subscales - inspirational motivation (e.g., "talks optimistically about the future"), idealized 
Table 2 Multivariate analysis of variance summary for IBQ.

\begin{tabular}{|c|c|c|c|c|c|c|c|c|c|c|}
\hline \multicolumn{7}{|l|}{ MANOVA } & \multicolumn{4}{|c|}{ Univariate analysis of variance } \\
\hline $\begin{array}{l}\text { Ind. variable } \\
\text { IBQ }\end{array}$ & Wilks' & $F$ & $p$ & Roy's & $F$ & $p$ & Dep. variables & $F$ & $d f$ & $p$ \\
\hline \multirow[t]{10}{*}{ Education } & 0.88 & 1.4 & 0.128 & 0.08 & 1.75 & 0.081 & & & & \\
\hline & & & & & & & Legitimate & 0.26 & 2 & 0.769 \\
\hline & & & & & & & Rational persuasion & 0.19 & 2 & 0.828 \\
\hline & & & & & & & Personal appeals & 0.88 & 2 & 0.415 \\
\hline & & & & & & & Pressure & 1.02 & 2 & 0.364 \\
\hline & & & & & & & Exchange & 0.92 & 2 & 0.399 \\
\hline & & & & & & & Ingratiation & 1.39 & 2 & 0.251 \\
\hline & & & & & & & Consultation & 1.13 & 2 & 0.325 \\
\hline & & & & & & & Inspirational appeals & 0.12 & 2 & 0.888 \\
\hline & & & & & & & Coalition tactics & 0.28 & 2 & 0.757 \\
\hline \multirow[t]{10}{*}{ Age } & 0.91 & 1.07 & 0.382 & 0.08 & 1.67 & 0.099 & & & & \\
\hline & & & & & & & Legitimate & 0.13 & 2 & 0.878 \\
\hline & & & & & & & Rational persuasion & 0.80 & 2 & 0.453 \\
\hline & & & & & & & Personal appeals & 0.01 & 2 & 0.992 \\
\hline & & & & & & & Pressure & 1.04 & 2 & 0.356 \\
\hline & & & & & & & Exchange & 2.87 & 2 & 0.059 \\
\hline & & & & & & & Ingratiation & 0.74 & 2 & 0.476 \\
\hline & & & & & & & Consultation & 1.75 & 2 & 0.176 \\
\hline & & & & & & & Inspirational appeals & 1.08 & 2 & 0.341 \\
\hline & & & & & & & Coalition tactics & 0.19 & 2 & 0.824 \\
\hline \multirow[t]{10}{*}{ Educ $\times$ age } & 0.76 & 1.55 & 0.022 & 0.17 & 3.58 & 0.000 & & & & \\
\hline & & & & & & & Legitimate & 0.80 & 4 & 0.524 \\
\hline & & & & & & & Rational persuasion & 1.85 & 4 & 0.120 \\
\hline & & & & & & & Personal appeals & 0.57 & 4 & 0.683 \\
\hline & & & & & & & Pressure & $4.44^{* *}$ & 4 & 0.002 \\
\hline & & & & & & & Exchange & 0.41 & 4 & 0.802 \\
\hline & & & & & & & Ingratiation & 1.04 & 4 & 0.388 \\
\hline & & & & & & & Consultation & 1.42 & 4 & 0.227 \\
\hline & & & & & & & Inspirational appeals & 0.74 & 4 & 0.563 \\
\hline & & & & & & & Coalition tactics & 1.07 & 4 & 0.374 \\
\hline \multirow[t]{10}{*}{ Gender } & 0.86 & 3.53 & 0.001 & 0.17 & 3.53 & 0.001 & & & & \\
\hline & & & & & & & Legitimate & 0.04 & 1 & 0.833 \\
\hline & & & & & & & Rational persuasion & 2.13 & 1 & 0.149 \\
\hline & & & & & & & Personal appeals & 1.38 & 1 & 0.242 \\
\hline & & & & & & & Pressure & $10.32^{* *}$ & 1 & 0.002 \\
\hline & & & & & & & Exchange & 1.90 & 1 & 0.170 \\
\hline & & & & & & & Ingratiation & 0.20 & 1 & 0.658 \\
\hline & & & & & & & Consultation & 0.34 & 1 & 0.562 \\
\hline & & & & & & & Inspirational appeals & 2.15 & 1 & 0.144 \\
\hline & & & & & & & Coalition tactios & 0.03 & 1 & 0.857 \\
\hline \multirow[t]{10}{*}{ Educ $\times$ gender } & 0.88 & 1.46 & 0.100 & 0.10 & 2.16 & 0.026 & & & & \\
\hline & & & & & & & Legitimate & 1.38 & 2 & 0.253 \\
\hline & & & & & & & Rational persuasion & 0.39 & 2 & 0.675 \\
\hline & & & & & & & Personal appeals & 1.38 & 2 & 0.254 \\
\hline & & & & & & & Pressure & $5.15^{* *}$ & 2 & 0.007 \\
\hline & & & & & & & Exchange & 0.33 & 2 & 0.720 \\
\hline & & & & & & & Ingratiation & 0.04 & 2 & 0.962 \\
\hline & & & & & & & Consultation & 0.61 & 2 & 0.543 \\
\hline & & & & & & & Inspirational appeals & 0.79 & 2 & 0.455 \\
\hline & & & & & & & Coalition tactics & 0.66 & 2 & 0.518 \\
\hline \multirow[t]{4}{*}{ Age $\times$ gender } & 0.94 & 0.69 & 0.819 & 0.06 & 1.18 & 0.307 & & & & \\
\hline & & & & & & & Legitimate & 1.65 & 2 & 0.195 \\
\hline & & & & & & & Rational persuasion & 2.16 & 2 & 0.118 \\
\hline & & & & & & & Personal appeals & 1.59 & 2 & 0.207 \\
\hline
\end{tabular}


Table 2 (continued)

\begin{tabular}{|c|c|c|c|c|c|c|c|c|c|c|}
\hline \multicolumn{7}{|l|}{ MANOVA } & \multicolumn{4}{|c|}{ Univariate analysis of variance } \\
\hline \multirow[t]{7}{*}{$\begin{array}{l}\text { Ind. variable } \\
\text { IBQ }\end{array}$} & Wilks' & $F$ & $p$ & Roy's & $F$ & $p$ & Dep. variables & $F$ & $d f$ & $p$ \\
\hline & & & & & & & Pressure & 2.15 & 2 & 0.120 \\
\hline & & & & & & & Exchange & 0.88 & 2 & 0.418 \\
\hline & & & & & & & Ingratiation & 0.83 & 2 & 0.438 \\
\hline & & & & & & & Consultation & 1.58 & 2 & 0.209 \\
\hline & & & & & & & Inspirational appeals & 0.57 & 2 & 0.566 \\
\hline & & & & & & & Coalition tactics & 1.15 & 2 & 0.320 \\
\hline
\end{tabular}

$* * p<0.01$

influence (e.g., "instills pride in others for being associated with him/her"), individualized consideration (e.g., "spends time teaching and coaching"), and intellectual stimulation (e.g., "re-examines critical assumptions to question whether they are appropriate") - each achieved acceptable reliability estimates ( $\alpha=0.69$ to 0.81 ).

Leaders' influence tactics were measured with Yukl's Influence Behavior Questionnaire (IBQ; Yukl \& Falbe, 1990). Targets reported their perceptions of leaders' use of influence tactics on a scale that ranged from 1 (never) to 5 (always). The 50 items make up nine subscales: legitimating (e.g., "says that a request is consistent with organization rules and policies"); exchanges (e.g., "says that I will make it worth your effort if you do what I ask"); pressure (e.g., "demands that you carry out a request promptly"); coalition (e.g., "asks other people to provide you with evidence supporting a proposal or plan"); inspirational appeal (e.g., "explains in an enthusiastic manner why a proposed task or project is important and worthy of your best efforts"); personal appeal (e.g., "appeals to your friendship when asking you to do something"); consultative (e.g., "asks you to help plan a task or activity that will require your support or assistance"); ingratiation (e.g., "compliments you on past accomplishments before asking you to do another task"); rational persuasion (e.g., "uses facts and logic to make a persuasive case for a proposed plan of action that he/ she wants implemented"). The questionnaire has been used extensively in research on influence tactics and has been reported as reliable; alpha coefficients in previous research ranged from 0.67 to 0.89 (Falbe \& Yukl, 1992; Yukl \& Tracey, 1992; Yukl et al., 1993).

\section{Procedures}

Leaders elected to participate in this study through their enrollment in local and regional leadership development workshops offered through community development and open enrollment efforts. They were given the opportuni- ty to decline participation at any time prior to, during, or after the workshop was completed.

Each participating leader was asked to distribute the MLQ and IBQ (rater versions) to all followers, regardless of number. Each rater received an informed consent letter from the first author and were asked to keep the letter as proof of his or her consent to participate. Raters returned coded instruments anonymously to the first author via postage-paid U.S. mail. Although this data collection method creates a non-probability snowball sample (Dillman, 2000), the population list included all members of the population, which improved randomization. Power analysis indicated that a sample size of 200 dyads would reveal small effects, $r^{2}=0.04$; two tailed, $p<0.05$ (J. Cohen \& P. Cohen, 1983). The achieved sample size of 234 dyads satisfied these power requirements. The followers' high return rate of $70 \%$ may be attributed to the leaders' communicated commitment to the leadership development efforts.

Analysis of the raters' MLQ began by parceling 20 transformational items into four subscales. Analysis of the raters' IBQ began by parceling the 50 items into ten subscales.

\section{Results}

MANOVA results revealed that the leader's gender and education explained significant differences in followers' ratings of leadership behaviors and influence tactics used by the leaders. All rater subscale values for each leader were averaged, which resulted in 56 parceled sets of leader subscales. The areas in which these differences were most significant are management by exception, idealized influence, individualized consideration, inspirational appeal, intellectual stimulation, transformational, effectiveness, extra effort, laissez-faire, and pressure (see Tables 1 and 2).

\section{Individual variables}

Gender had no significant effects on ratings of transactional and/or transformational leadership behaviors in 


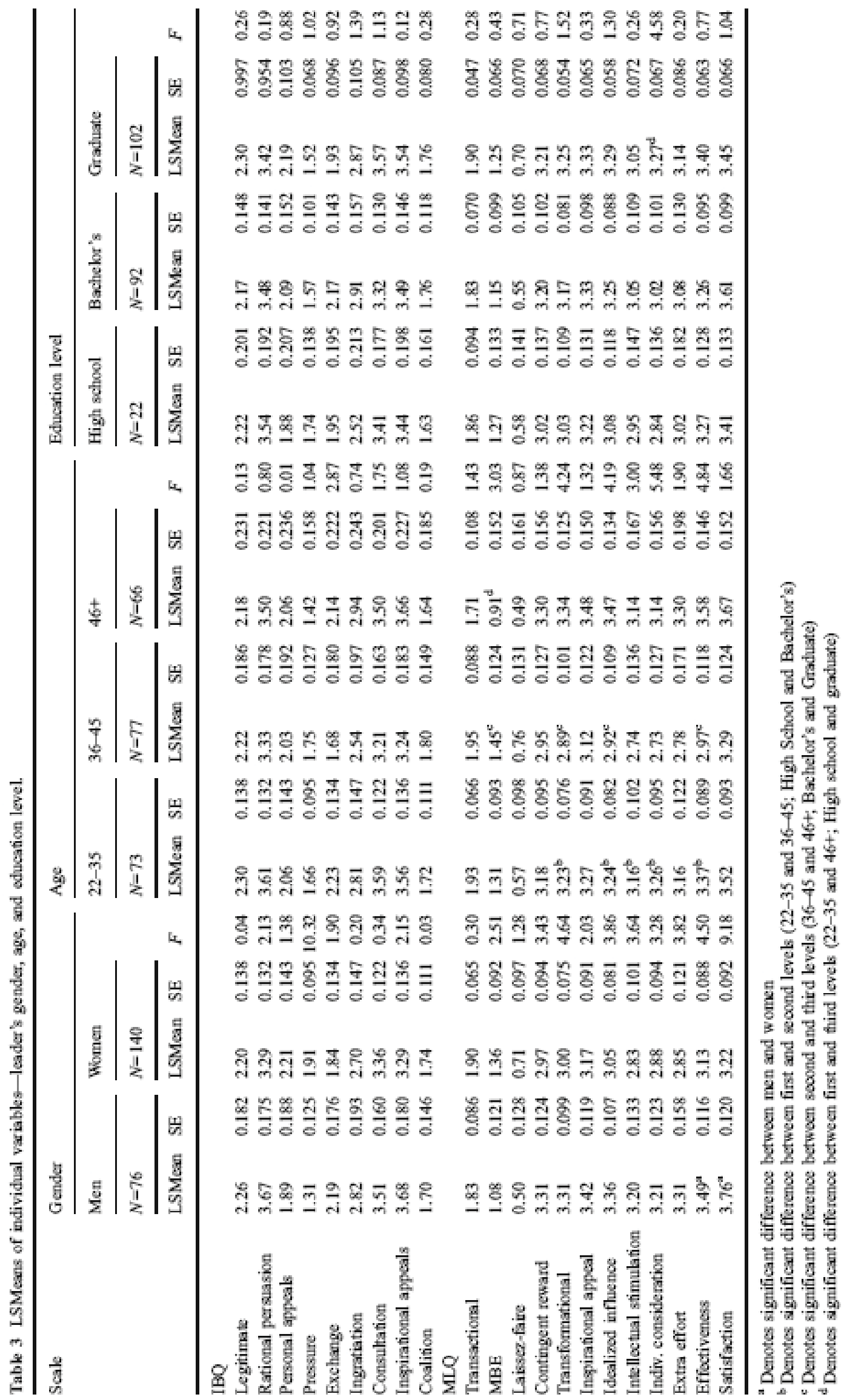




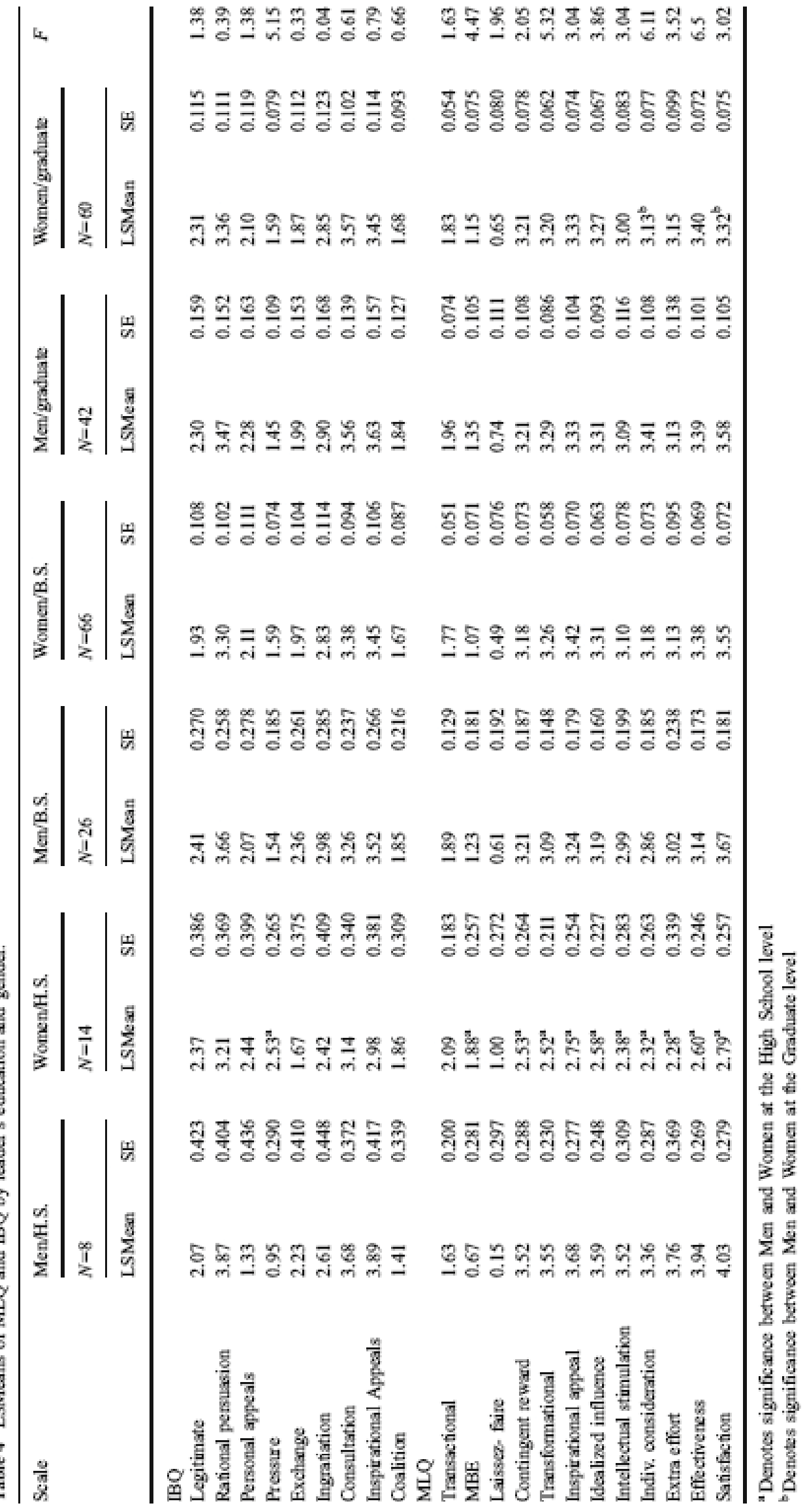


Fig. 1 Education and gender interaction for management by exception.

\section{MBE by Education and Gender}

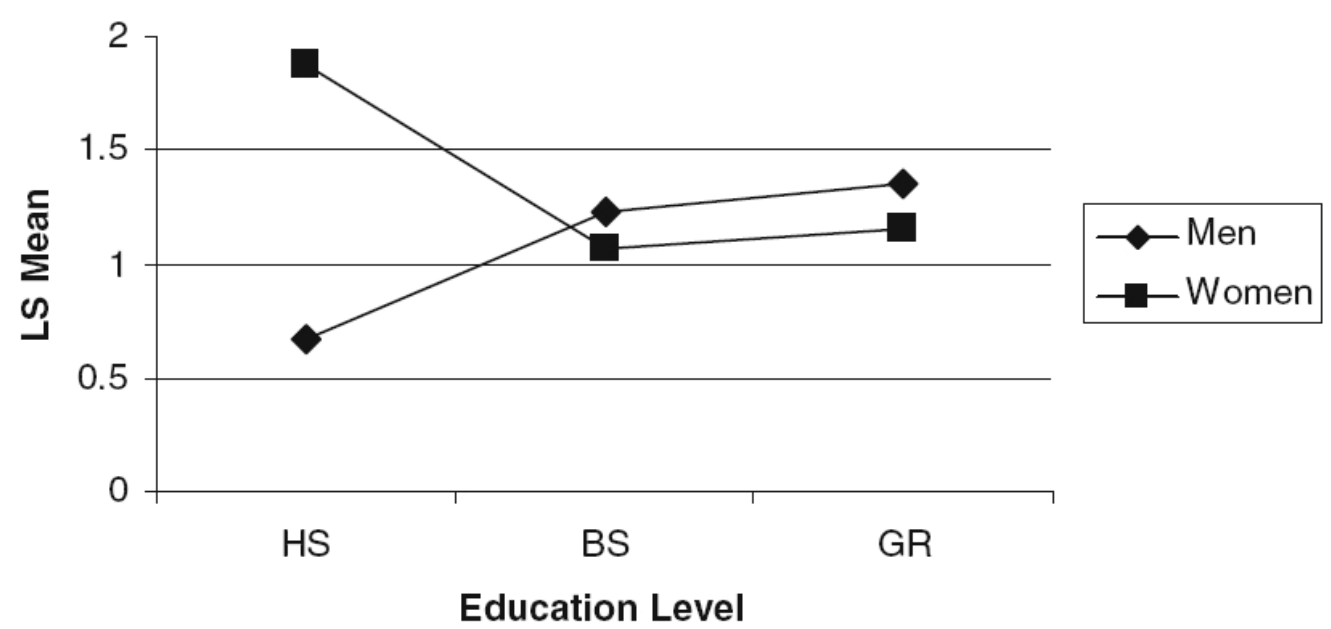

the present study (See Table 1). However, the main effects of gender on influence tactics were significant; women were rated as using significantly more pressure tactics than were men (See Tables 2 and 3).

The effect of the leader's age on followers' ratings of transactional and/or transformational leadership style was significant, as clear differences emerged based on the age group occupied by the leader $(22-35 ; 36-45$; $46+)$. Overall the $46+$ age group was rated the highest for transformational leadership. The same is true for the subscales idealized influence, intellectual stimulation, individualized consideration, and effectiveness. Lowest ratings were given to the 36-45 age groups for intellectual stimulation and individualized consideration. Leader's age had no significant effect on raters' perceptions of influence tactics used.
The leader's level of education produced a significant main effect on followers' perceptions of transactional and/ or transformational behaviors. Significant differences were found among educational level groups for individualized consideration; those leaders who had earned an advanced degree exhibited the highest rating level in this subscale. Leaders' educational level showed no main effect on ratings of influence tactics.

Interaction effects

Educational level and gender together affected followers' perceptions of both leadership style and influence tactics. Significant differences were noted for management by exception, transformational, idealized influence, individualized consideration, extra effort, and
Fig. 2 Education and gender interaction for transformational leadership.

\section{Transformational by Education and Gender}

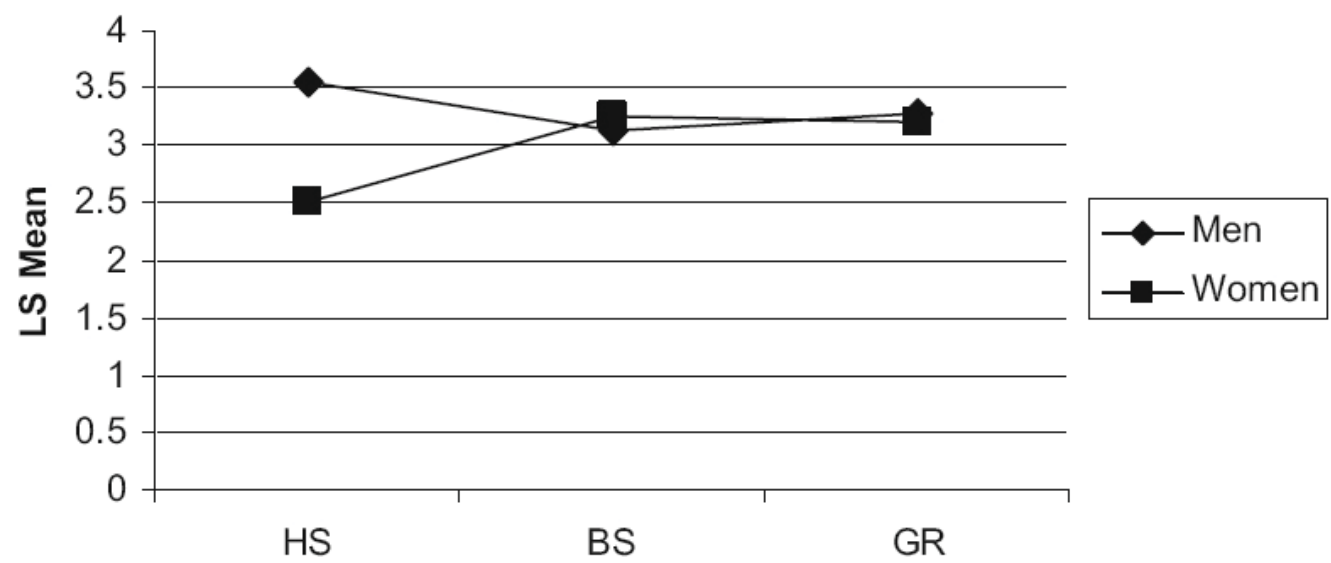

Education Level 
Fig. 3 Education and gender interaction for pressure.

\section{Pressure by Education and Gender}

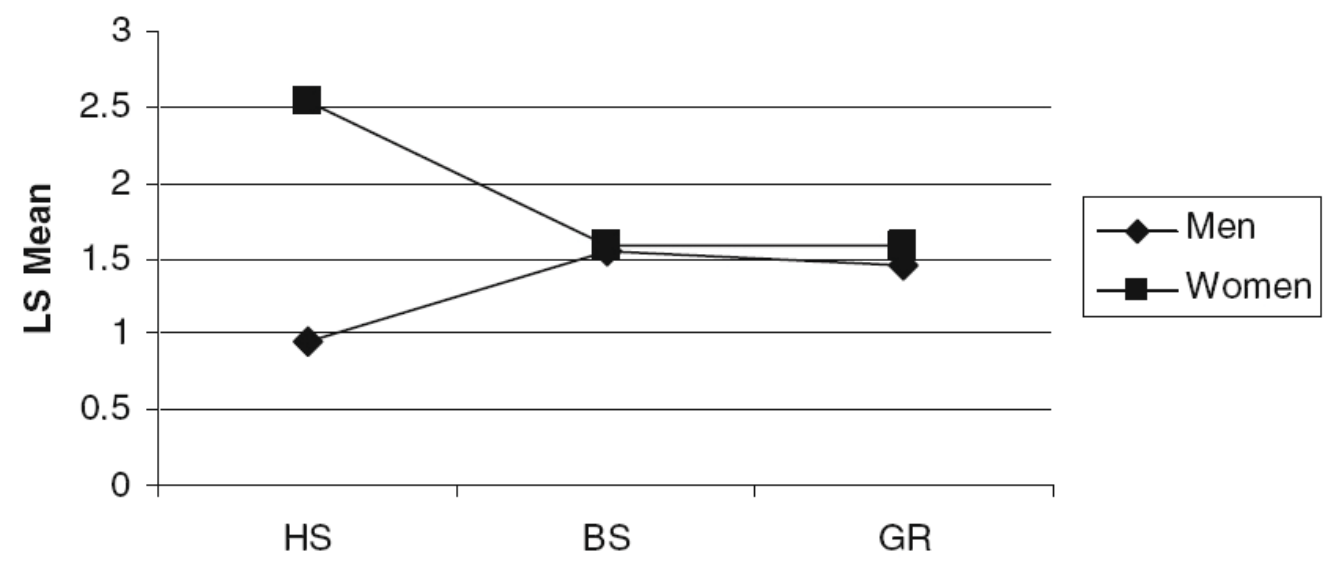

Education Level

effectiveness (See Table 4). The greatest differences were found in leaders at the high school educational level. Followers rated women at this level as significantly more likely than men to favor management by exception behaviors. Men at this level were rated by followers as significantly more likely than women to favor transformational, inspirational appeal, idealized influence, intellectual stimulation, and individualized consideration behaviors. Men were rated by followers significantly higher than women on extra effort, effectiveness, and satisfaction. The only influence tactic on which the ratings of men and women differed significantly was pressure - women with no more than a high school education were perceived as using more pressure tactics than were men at the same educational level. In all cases, the differences diminished as educational levels increased (See Figs. 1, 2, and 3).

The combination of age and gender did not produce an overall main effect on leadership styles or influence tactics (See Tables 1 and 2).

\section{Discussion}

We found that gender alone did not affect transactional and transformational leadership, but we did find gender-influenced differences at the lowest level of education (high school). Although noteworthy, this difference was found with small cell sizes, which require confirmatory replication to generalize. Although we did find gender differences in the perceived use of pressure tactics (women were perceived to use pressure more often than men), it is not clear if this finding indicates a higher perceived use of pressure tactics or differences in the per- ception of tactics used by women and men, as a woman is "sometimes penalized by prejudiced reactions that would not be directed toward her male counterparts" (Eagly et al., 1992, p. 3.).

The independent variable of "life experiences" may help to explain the interaction effects of education and gender and of education and age (see Avolio, 1994). In both cases the greatest differences were found at the lowest level of education (high school). These differences diminished at higher levels of education (bachelor's or graduate degree), which provides empirical support for what has been treated in the field as a fait accompli.

These findings reinforce the importance of studying the contextual nature of gender differences in leadership (van Engen \& Willemsen, 2004). If the contextual nature of gender differences had not been a focus of the present study, we would have concluded inaccurately that no gender difference existed and thus missed the effect of gender on ratings of transformational leadership behavior. Previous work that showed no gender difference in behaviors may have provided similar patterns had the contextual nature been examined. We strongly encourage future researchers to consider the contextual nature of gender, and we encourage re-analysis of prior studies (where data are available) to assess the contextual nature of gender differences. If women and men are to be valued equally as leaders, it is imperative that we understand the differences that may occur either as a result of gender or as a result of workers' reactions to leaders based on gender. Future studies, as well as the reexamination of previous studies, may eventually help us come closer to answering the "age-old" question: "Are leaders made or born?" 


\section{References}

Acker, S. (Ed.) (1989). Teachers, gender, and careers. New York: Falmer.

Antonakis, J. (2001). The validity of the transformational, transactional, and laissez-faire leadership model as measured by the multifactor leadership questionnaire (MLQ5X). Doctoral dissertation, Walden University.

Avolio, B. J. (1994). The natural: Some antecedents to transformational leadership. International Journal of Public Administration, 17, 1559-1581.

Barbuto, J. E., Scholl, R. W., Hickox, C. F., \& Boulmetis, J. (2001). A field study of the relation between leaders' anticipation of targets' resistance and targets' report of influence tactics used by leaders in dyadic relations. Psychological Reports, 88, 835-944.

Barry, B., \& Shapiro, D. L. (1992). Influence tactics in combination: The interactive effects of soft versus hard tactics and rational exchange. Journal of Applied Social Psychology, 22, 1429-1441.

Bartol, K. M., \& Martin, D. C. (1986). Women and men in task groups. In R. D. Ashmore \& F. K. Del Boca (Eds.), The social psychology of femalemale relations (pp. 259-310). Orlando, FL: Academic.

Bass, B. M. (1985). Leadership and performance beyond expectations. New York: Free.

Bass, M., \& Avolio, B. (1992). Developing transformational leadership: 1992 and beyond. Journal of European Industrial Training, 14, 21-37.

Bass, B. M., \& Stogdill, R. M. (1990). Bass \& Stogdill's handbook of leadership: Theory, research, \& managerial applications. New York: Free.

Blank, T. O., \& Levesque, M. J. (1993). Constructing success and failure: Age differences in perceptions and explanations of success and failure. International Journal of Aging and Human Development, 37, 105-119.

Bronfenbrenner, U. (1961). Some familial antecedents of responsibility and leadership in adolescents. In L. Petrol \& B. M. Bass (Eds.), Leadership and interpersonal behavior (pp. 239-271). New York: Holt, Rinehart and Winston.

Broverman, I. K., Vogel, S. R., Broverman, D. M., Clarkson, F. E., \& Rosenkrantz, P. S. (1972). Sex role stereotypes: A current appraisal. Journal of Social Issues, 29, 59-78.

Burgoon, M., Dillard, J. P., \& Doran, N. E. (1983). Friendly or unfriendly persuasion: The effects of violations by males and females. Human Communication Research, 10, 283-294.

Cann, A., \& Siegfried, W. D. (1990). Gender stereotypes and dimensions of effective leader behavior. Sex Roles, 23, 413-419.

Carless, S. A. (1998). Gender differences in transformational leadership: An examination of superior, leader, and subordinate perspectives. Sex Roles, 39, 887-902.

Carli, L. L. (1999). Gender, interpersonal power, and social influence. Journal of Social Issues, 55, 81-99.

Carothers, B. J., \& Allen, J. B. (1999). Relationships of employment status, gender role, insult, and gender with use of influence tactics. Sex Roles, $41,375-387$.

Chetkow-Yanoov, B. (1986). Leadership among the ages: A study of engagement among third-age professionals in Israel. Aging and Society, 6, 5574.

Chliwniak, L. (1997). Higher education leadership: Analyzing the gender gap. ASHE-ERIC Higher Education Report, 25.

Chusmir, L. H., \& Mills, J. (1989). Gender differences in conflict resolution styles of managers: At work and at home. Sex Roles, 20, 149-163.

Chusmir, L. H., \& Parker, B. (1992). Success strivings and their relationship to affective work behaviors: Gender differences. Journal of Social Psychology, 132, 87-100.

Cohen, J., \& Cohen, P. (1983). Applied multiple regression/correlation analysis for the behavioral sciences. Mahwah, NJ: Erlbaum.

Cusack, S. A. (1994). Developing leadership in the third age: An ethnograph- ic study of leadership in a seniors' center. Journal of Applied Gerontology, 13, 127-143.

Cusack, S. A., \& Thompson, W. J. A. (1992). Leadership training in the third age: The research and evaluation of a leadership and personal development program for the retired. Journal of Applied Gerontology, 11, 343360 .

Davis, S. W., Best, D. L, \& Williams, J. E. (1982). Sex-trait stereotypes in the self-and peer descriptions of third grade children. Sex Roles, 8, 315-331.

Deaux, K., \& Lewis, L. L. (1984). Structure of gender stereotypes: Interrelationships among components and gender label. Journal of Personality and Social Psychology, 46, 991-1004.

Dillman, D. A. (2000). Mail and internet surveys: The tailored design meth$o d$. New York: Wiley.

Druskat, V. (1994). Gender and leadership style: Transformational and transactional leadership in the Roman Catholic Church. Leadership Quarterly, 5, 99-119.

Duane, M. J. (1989). Sex differences in styles of conflict management. Psychological Reports, 65, 1033-1034.

DuBrin, A. J. (1991). Sex and gender differences in tactics of influence. Psychological Reports, 68, 635-646.

Eagly, A. H., Johannesen-Schmidt, M. C., \& van Engen, M. L. (2003). Transformational, transactional, and laissez-faire leadership styles: A metaanalysis comparing women and men. Psychological Bulletin, 129, 569591.

Eagly, A. H., \& Johnson, B. T. (1990). Gender and leadership style: A metaanalysis. Psychological Bulletin, 108, 233-256.

Eagly, A. H., \& Karau, S. J. (1991). Gender and the emergence of leaders: A meta-analysis. Journal of Personality and Social Psychology, 60, 685710

Eagly, A. H., Karau, S. J., \& Makhijani, M. G. (1995). Gender and the effectiveness of leaders: A meta-analysis. Psychological Bulletin, 117, 125145

Eagly, A. H., Makhijani, M. G., \& Klonsky, B. G. (1992). Gender and the evaluation of leaders: A meta-analysis. Psychological Bulletin, 111, 322.

Falbe, C., \& Yukl, G. (1992). Consequences for managers of using single influence tactics and combinations of tactics. Academy of Management Journal, 35, 638-652.

Ganzel, A. K. (1999). Adolescent decision making: The influence of mood, age, and gender on the consideration of information. Journal of Adolescent Research, 14, 289-319.

Gutek, B. A. (1985). Sex and the workplace. San Francisco: Jossey-Bass.

Hackman, M. Z., Furniss, A. H., Hills, M. J., \& Paterson, T. J. (1992). Perceptions of gender-role characteristics and transformational and transactional leadership behaviours. Perceptual and Motor Skills, 75, 311-319.

Helgeson, S. (1990). The female advantage: Women's ways of leadership. New York: Doubleday Currency.

Horsman, J. H. (2001). Perspectives of servant-leadership and spirit in organizations. Dissertation Abstracts International Section A: Humanities and Social Sciences, 62(3-A), 1119.

Hughes, R. L., Ginnett, R. C., \& Curphy, G. J. (1993). Leadership: Enhancing the lessons of experience. Boston: Irwin.

Itzhaky, H., \& York, A. S. (2000). Empowerment and community participation: Does gender make a difference? Social Work Research, 24, 225235.

Jacobson, M. B., \& Effertz, J. (1974). Sex roles and leadership perceptions of the leaders and the led. Organizational Behavior and Human Performance, 12, 383-396.

Jenkins, S. R. (2000). Defining gender, relationships, and power (Introduction to the special issue). Sex Roles, 42, 467-494. 
Kazan, A. L. (2000). Exploring the concept of self-leadership: Factors impacting self-leadership of Ohio Americorps members. Dissertation Abstracts International: Section A: Humanities \& Social Sciences, 60(11-A), 3870.

Kipnis, D., Schmidt, S. M., \& Wilkinson, I. (1980). Intraorganizational influence tactics: Explorations in getting one's way. Journal of Applied Psychology, 54, 440-452.

Kirtley, M. D., \& Weaver, J. B. (1999). Exploring the impact of gender role self-perception on communication style. Women's Studies in Communication, 22, 190-210.

Komives, S. R. (1991). Gender differences in the relationship of hall directors' transformational and transactional leadership and achieving styles. Journal of College Student Development, 32, 155-165.

Kovar, S. K., \& Overdorf, V. (1995). Scholarly productivity as a function of graduate training, workplace, and gender. Women in Sport and Physical Activity Journal, 4(2), 1-21.

Lamude, K. G. (1993). Supervisors' upward influence tactics in same-sex and cross-sex dyads. Perceptual and Motor Skills, 77, 1067- 1070.

Leithwood, K., \& Jantzi, D. (1997). Explaining variation in teachers' perceptions of principals' leadership: A replication. Journal of Educational Administration, 35, 312-330.

Lewis, A. E. (1998). The influence of gender and organization level of perceptions of leader behaviors: A self and supervisor comparison. Sex Roles, 39, 479-502.

Lips, H. M. (2000). College students' visions of power and possibility as moderated by gender. Psychology of Women Quarterly, 24, 39-44.

Nieva, V. F., \& Gutek, B. A. (1981). Women and work: A psychological perspective. New York: Praeger.

O’Connor, J. S. (1996). Labour market participation, gender, and citizenship. Current Sociology, 44, 78-101.

Ojode, L. A., Walumbwa, O., \& Kuchinke P. (1999, April). Developing human capital for the evolving work environment: Transactional and transformational leadership within an instructional setting. Paper presented at the meeting of the Midwest Academy of Management, Lincoln, NE.

Payden, B. L. (1997). The relationship between perceived leadership behaviors and job satisfaction based on age, gender, and education level variables. Dissertation Abstracts International: Section A: Humanities \& Social Sciences, 57(7-A), 3127.

Porter, N., Geis, F. L., \& Jennings, J. (1983). Are women invisible as leaders? Sex Roles, 9, 1035-1049.

Radecki, C. M., \& Jaccard, J. (1996). Gender-role differences in decisionmaking orientations and decision-making skills. Journal of Applied Social Psychology, 26, 76-95.

Rasor, C. E. (1995). An analysis of the relationship between personality preference traits of executive level and mid-level law enforcement/corrections leaders and exemplary leadership practices. Dissertation Abstracts International: Section A: Humanities \& Social Sciences, 56(4-A), 1436.

Rosener, J. D. (1990). Ways women lead: The command-and-control leadership style association with men is not the only way to succeed. Harvard Business Review, 68,119-125.

Schein, V. E. (1973). The relationship between sex-role stereotypes and requisite management characteristics. Journal of Applied Psychology, 57, 95100.

Schein, V. E., Mueller, R., \& Jacobson, C. (1989). The relationship between sex role stereotypes and requisite management characteristics among college students. Sex Roles, 20, 103-110.

Schneider, B., Paul, M. C., White, S. S., \& Holcombe, K. M. (1999). Understanding high school student leaders: Predicting teacher ratings of leader behavior. Leadership Quarterly, 10, 609-636.

Sorenson, P. S., Hawkins, K., \& Sorenson, R. L. (1995). Gender, psychological type, and conflict preference. Management Communication Quarter$l y, 9,115-126$.
Sutherland, M. B. (1999). Gender equity in success at school. International Review of Education, 45, 431-444.

Taylor, T. R. (1998). Factors influencing the effectiveness of cross-functional work teams in a research and development organization. Dissertation Abstracts International: Section B: The Sciences \& Engineering, 58(10B), 5685 .

Tepper, B. J., Brown, S. J., \& Hunt, M. D. (1993). Strength of subordinates' influence tactics and gender congruency effects. Journal of Applied Psychology, 23, 1903-1919.

Thacker, R. A. (1995). Gender, influence tactics, and job characteristics preferences: New insights into salary determination. Sex Roles, 32, 617-638.

Thomas, B. B. (1996). The relationship of leadership style to teacher leadership preferences. Dissertation Abstracts International: Section A: Humanities \& Social Sciences, 57(1-A), 0064.

Thompson, M. D. (2000). Gender, leadership orientation, and effectiveness: Testing the theoretical models of Bolman, Deal, and Quinn. Sex Roles, 42, 969-993.

van Engen, M. L., van der Leeden, R., \& Willemsen, T. M. (2001). Gender, context, and leadership styles: A field study. Journal of Occupational and Organizational Psychology, 74, 581-598.

van Engen, M. L., \& Willemsen, T. M. (2004). Sex and leadership styles: A meta-analysis of research published in the 1990s. Psychological Reports, 94, 3-18.

Vecchio, R. P., \& Boatwright, K. J. (2002). Preferences for idealized styles of supervision. Leadership Quarterly, 13, 327-342.

White, J. W. (1988). Influence tactics as a function of gender, insult, and goal. Sex Roles, 18, 433-448.

Williamson, A. (2000). Gender issues in older adults' participation in learning: Viewpoints and experiences of learners in the university of the third age. Educational Gerontology, 26, 49-67.

Wilson, C. D., \& Hossain, M. A. (1999). Gender and scholarly productivity in administration in social work, 1977-1995. Administration in Social Work, 23, 67-84.

Yukl, G., \& Falbe, C. (1990). Influence tactics and objectives in upward, downward, and lateral influence attempts. Journal of Applied Psychology, 75, 132-140.

Yukl, G., Falbe, C. M., \& Youn, J. Y. (1993). Patterns of influence behavior for managers. Group and Organizational Management, 18, 5-29.

Yukl, G., \& Tracey, B. (1992). Consequences of influence tactics used with subordinates, peers, and the boss. Journal of Applied Psychology, 77, 525-535.

Zacharatos, A., Barling, J., \& Kelloway, K. (2000). Development and effects of transformational leadership in adolescents. Leadership Quarterly, $11,211-217$.

Zanna, M. P., \& Pack, S. J. (1975). On the self-fulfilling nature of apparent sex differences in behavior. Journal of Experimental Social Psychology, 11, 583-591. 